\title{
The Theoretical Model of the System of Continuous Architectural and Art Education in a Large Region
}

\author{
Adelya Gazizova \\ Department of Decorative and Applied Art \\ Samara State Institute of Culture \\ Samara, Russia \\ E-mail: adelya2006-77@mail.ru
}

\begin{abstract}
The article examines the influence of architectural and art education on the post-industrial development of civilization, the inclusion of design education into school curriculum of advanced countries and the current status in Russia. The state of the problem of architectural and artistic education and the need for its modernization in Russia. The theoretical model of continuous architectural and artistic education in a large region has been proposed, this model includes the systems of pre-university, vocational and postgraduate education.
\end{abstract}

Keywords-system of continuous architectural and artistic education; higher education; USUAA; Ekaterinburg; Gzhel region; architectural and art education in Russia; design education in the $U K$ and Japan; the concept of continuous education

\section{INTRODUCTION}

At the threshold of the new millennium, architectural and art education and education in general becomes a strategic resource for the development of civilization. Civilization progresses only when education is progressing.

Today qualitative changes occur in all professional spheres, including the sphere of education. These changes related to the change and formation of a new type of civilization - the post-industrial civilization.

A person is considered as a creative and self-developing personality, individually evaluating changes in the life and profession and individually responding to these changes by his personal actions, rules, methods, and worldview. The creative personality becomes the main unit not only in society in general, but also in education in particular, where personal activity and creativity occupy an important place. The social demand for education is formed by the society itself; the man himself is willing to learn. In accordance with such an approach, the student must independently determine and self-develop in the sphere of education and professional activity.

In the modern world there is a huge amount of creative activity, which requires creative thinking. A creative, thinking and educated person is required in various fields of human activity, from programming to travelling to space, from the executing role to the leading position.
For this model of self-education, self-determination and self-development to work, it is necessary to create the appropriate prerequisites in the education system itself, in the general cultural direction.

At different times in different countries the belief that not architecture but design should become an effective tool of transformation and humanization of a reality surrounding a person was ripening [1]. The "Concept of Continuous Architectural Education" was developed and implemented in Russia, this concept was highlighted in the work of A P.Kudryavtsev, A. V.Stepanov, N. F. Metlenkov and Yu. V. Volchok. The domestic concept of national architectural education as a system of continuous education incudes three steps: pre-university, university, and post-graduate education

According to the author, one cannot assert with full confidence which of the types of art education will have positive impact on cultural, social, and economic life of the society, since each student has his own individual abilities, talents, and preferences. Many live in rural areas and small towns, so not everyone is able to walk the path continuous architectural or design education. In various regions of Russia folk art crafts are preserved and developed: Abramtsevo, Gzhel, Talashkino, Gorodets, Zhostovo, Palekh, Kubachi, Fedoskino, Khokhloma, etc.

According to the earlier research, the author of the article, under the concept of architectural and art education, implies the education at various levels of the educational process of architects, designers, artists, graphic artists, sculptors, and specialists in decorative and applied arts. The author considers continuous architectural and art education in range from additional extracurricular education, secondary vocational, and higher education to postgraduate education.

\section{THE STATE OF THE PROBLEM OF ARCHITECTURAL AND ARTISTIC EDUCATION AND THE NEED FOR ITS MODERNIZATION IN RUSSIA}

1960-1970 were a turning point in organizing of preuniversity art education. According to the Provision on extracurricular institutions approved by the Ministry of Education of the USSR, the RSFSR, the Central Committee of the Komsomol, the Ministry of Culture of the USSR under the Council of Ministers of the USSR in 1960-1971, Palaces 
and Houses of the Pioneers and Schoolchildren were established (club, studios for fine arts, sculpture, and architectural creativity), Children's Art Schools [2]. Since 1976 art schools had been opened; they usually were cooperated with general education schools or accommodated in specially designed standard buildings.

Until the mid-seventies of the XX century in Russia, a centralized system of higher art education prevailed. All the large and prestigious higher educational institutions of the country were in the largest cities, where young people went to study from all over the country, and then the graduates were sent to different parts of the Soviet Union according to strict distribution. In the 1970-1980's the time had come for the birth of regional schools that adopted the traditional methods of universities but taken into account local peculiarities and traditions.

In the mid-1970's on the basis of constructionengineering and polytechnic universities in Krasnoyarsk, Irkutsk, Kazan, Samara and Saratov new architectural faculties were opened, today they have turned into mature architectural schools. They, in turn, expand, develop, and, separating, form new architectural and design schools. The emergence of higher schools owes to the opening in different regions of the branches of the capital universities [3].

In the 90 s of the last century, design faculties and departments opened in Nizhny Novgorod, Vladivostok, Rostov-on-Don, Novosibirsk, Ufa, Kirov, Krasnodar, Stavropol, Kazan, Barnaul, Krasnoyarsk and Tyumen. The same changes affected the secondary vocational education institutions (secondary schools and colleges).

Today in Russia, the secondary vocational education institutions provide training in design, visual arts, architecture, decorative and applied arts and in the traditional areas of Russian folk-art culture.

The state-political and socio-economic transformations of the late 1980s and early 1990s made a significant impact on Russian education, making it possible to realize the academic autonomy of higher education institutions and to ensure the diversity of educational institutions, the variability of educational programs and the development of the multinational Russian school and the non-state education sector. However, the system-wide socio-economic crisis that occurred in the 1990s and socio-political changes significantly slowed down these positive changes.

There are many problems associated with the development and the reform of the existing national education systems. These problems are supplemented by the fact that Russia joined the Bologna Process in September 2003, when higher education was to move to a new degree system. This fact also affected the certain areas of architectural and artistic education.

In Russia, these problems were addressed through the development and implementation of the "Concepts of continuous education", "The Concept of Modernization of Russian Education for the Period Until 2010" [4] [5].

\section{TENDENCIES IN THE SYSTEM OF CONTINUOUS ARCHITECTURAL AND ART EDUCATION IN RUSSIA AND ABROAD}

The system of architectural and artistic education is characterized by the continuity of education from preschool age to higher education. This system consists of successive stages of training: first knowledge is acquired in preschool age, developed in school and out-of-school education and continued in secondary vocational and higher education. The positive and the best solution appears the concentration of several educational levels in one educational institution, as well as mutual cooperation or unification in complexes garden-school, school-college, college-university, and school-university. At the level of higher education, the link with manufacturing practice and with further employment opportunity is necessary. The system of continuous architectural and art education is inextricably connected with the socio-cultural level of population development and national and regional characteristics.

In advanced countries (Great Britain, Germany, Italy, Japan, France) the most important factor in the formation of the objective-spatial environment became design. In the educational programs of preschool, school age, courses in design, art were introduced.

The leading place among countries in which design is treated as a general line of humanitarian education occupies Great Britain, where this stream of school education has been elevated to the rank of state policy.

The objectives of the training are clearly defined in the preliminary report of the National Working Group for the development of the curriculum for design and technology. One of these goals is desire to teach children to study the problems available to them, to develop children's imagination, thinking process and ability to organize and plan their work, to evaluate results, to implement them, and to represent and protect these results. And the emphasis is made not on "early professionalization", but on utilizing the design potential for the child's multilateral development. Children are taught to formulate questions, to argue opinions, to develop ideas, to structure problems and to strengthen their capacity for self-esteem. At the same time, the abilities are developing simultaneously:

- Communicative: the ability to listen, discuss, report, visualize an idea;

- Mathematical: calculation and measurements, understanding of form and spatial relations;

- Manipulative: coordination of movements, ability to use tools during the process of creating;

- Social: joint reflection and discussion, tolerance to the opinion of the other, self-discipline;

- Personal: identity, curiosity, perseverance and flexibility of thinking.

In addition to school lessons, competitions, exhibitions, and fairs are held. They are conducted with the assistance of vocational education centers and the involvement of various 
interested public, educational, and industrial organizations [6].

In Japan since 1952, the state has contributed greatly to the development of design, as well as semi-public organizations or semi-public organizations did. Japanese teachers, using the achievements of Western pedagogy and the principles of education in the child of "independence and self-esteem" and "self-improvement of human," interpret the tasks of aesthetic education, through their specific Japanese attitude to the environment and to the world of things.

The design course in the Japanese school is not isolated it is interwoven with the training course "Art", in which students get acquainted and practically master the arts, crafts, painting and calligraphy. This course is closely connected with the lessons of "manual work" (shop classes). The main tasks in the Japanese methodological manuals are divided into three main groups: "education of humanity", "awareness of human connection with the environment," and "education of the creative personality" [7].

In Russia in the 70-80s of the last century the original methods of design education in children's design studios and art schools spread widely. The most famous studios: "Start", "EDAS" in Moscow, St. Petersburg, Sergey Talankin Design School, Da-Da Experimental School-Studio of Architecture and Design in Naberezhnye Chelny, Dashka in Kazan, School of the Young Architect and Designer, Art School in Vladivostok, and the Design Center in Orenburg. These and many other educational institutions have revolutionized children's art pedagogy, transforming the education in design, architecture and fine arts of young Russians into an interesting cycle of tasks and exercises that develop creative thinking and prepare for vocational education [8].

The Gzhel district is one of the major centers of national folk arts where the model of continuous art education system is being most successfully realized. The beginning of the creative path is the kindergarten, where children make their first attempts to convey their fantasies in clay (material). In general schools the program of professional orientation and artistic and aesthetic education continue; simultaneously children study at out-of-school institutions - children's art school and then continue education in the college and in Gzhel State University, learning tricks of the trade and taking over the experience of experts [9].

The Urals region is one of the developed regional architectural and artistic centers. Yekaterinburg has become a concentration of many art schools. The region has developed a system of continuous architectural and artistic education, which includes institutions of pre-school education, primary, secondary vocational, higher education, and additional education, cultural institutions, and consumer service facilities. This development is induced by the demand for specialists in production, in design, in research institutes and in private firms as well as by the very creative atmosphere that exists in the city. Ekaterinburg is the crossroads, a peculiar center of creative influences between Siberia and Europe, between the south and the north with its traditional folk art. Since the 1990s, the activity of artistic life in the city has increased, and there has been a surge in exhibition activity. New galleries and exhibition complexes are being opened, in this connection the existing museums start to work in a new way.

The major scientific and creative center of Ekaterinburg is the Ural State University of Architecture and Art. It dates back to 1947 from the Department of Architecture at the Ural Polytechnic Institute. In 1967 the department was reorganized into a branch of the Moscow Architectural Institute. At present, the Ural State University of Architecture and Art (USUAA) is a large academic and research and design and production center that trains specialists in four specialties: architecture, design, monumental and decorative art, and decorative and applied arts and folk crafts [10].

Thus, the tendencies of the inclusion, development, and influence of architecture and the design of fine art in the educational process at different levels occur in many developed countries, including Russia. Despite the fact that the system of educational institutions is different in countries, all share one goal: the humanization of the reality surrounding a person and the creation of a creative, selfsufficient and cultural personality.

\section{THE THEORETICAL MODEL OF THE SYSTEM OF CONTINUOUS ARCHITECTURAL AND ART EDUCATION} (SAHO)

In the dissertation research the author suggests the model of the system of continuous architectural and art education (SAHO) [11]. This system covers all educational institutions of an architectural and art direction, contributing to the development of the aesthetic and professional quality of an individual, and the institutions that influence a mature personality as objects of cultural and social significance.

The system of architectural and art education consists of:

- Systems of pre-university architectural and art education (preschool, school and additional education), which currently includes two concepts of education: propaedeutic and general culture education

- Systems of professional architectural and art education (primary professional, secondary vocational and higher vocational education);

- Postgraduate architectural and art education.

The model of the system of continuous architectural and art education cannot function without a system of cultural and entertainment centers, trade unions, personal social services, and production systems.

The system of pre-university architectural and artistic education. Propaedeutic education is mainly oriented towards early professionalization. The purpose of the propaedeutical architectural and artistic education is the preparation of an applicant for admission to the university [12].

General cultural architectural and art education presupposes the knowledge of the person, the environment that surrounds him, in which he lives (apartment, house, and 
city), so that the person appreciates the architectural and art heritage, adequately assesses the current situation and creatively tackles in the future.

These two concepts are inseparable in the learning process. The functions performed by pre-university education are several: cognitive (knowledgeable), artisticcreative, and architectural and art [13].

The structure of pre-university architectural and art education is represented by the following institutions: teaching and educational complexes (kindergartens and primary classes); art and architectural studios; specialized schools; lyceums, where the architecture is included in the curriculum; general education schools with in-depth study of specific subjects; children's art schools (DShI); children's fine art schools (DHSh).

Today, in Russia, the network of general art, fine arts, and decorative and applied arts is mostly developed, while the directions of architecture and design are present only in a few specialized schools, gymnasiums, or lyceums and only in major metropolitan cities or regions. These directions are rather unique and operate on the basis of a certain higher architectural school and they are supervised by this school. The second option, these directions arise as a result of the opening of studios and clubs by initiative teachers.

The system of professional architectural and artistic education consists of primary vocational, secondary professional, and higher professional education. Professional architectural and artistic education has two goals: the training of a specialist who would be sensitive to changes in society and to a social order and the education of a person and a creator. Ultimately, the artist, architect or designer should not be considered as a narrow specialist (a designer, performer and developer of external orders), but a broad specialist, multi-skilled specialist, and self-sufficient creative personality, who independently formulates the essence and content of the social order and independently chooses means to fulfill it (research, design, reconstruction, decorative, organizational, and economic).

Initial vocational education can include educational centers at architectural universities; lyceums; preliminary courses at architectural and artistic universities; tutors, preparing entrants to enrolment in the institute.

The structure of secondary vocational education is represented by educational institutions: art schools, pedagogical and vocational colleges, and colleges of culture.

The higher school should be the highest center, concentrating the creative stimulating atmosphere, and include:

- The educational function with general professional, general humanitarian, and socio-economic disciplines, mathematical, natural science, and professional disciplines, and disciplines at the student's choice, proposed by the university (faculty);

- The research and experimental sector;

- The national and regional component;
- "Square" - a vibrant meeting place for communication not only between students but also with concerned citizens to create a stimulating atmosphere;

- "Contest" - competitions, seminars, and academic competitions;

- The exposition center, which is open to the concerned public both from within and from outside;

- Travel - a large number of excursions and practices;

- Professional and creative environment - practice at enterprises and organizations and fulfillment of real orders.

The higher school should be an example to be followed and have the creative stimulating atmosphere, i.e. architectural and planning solution, functional and spatial environment, interior, and exterior should consistent with content of the learning process.

Postgraduate architectural and art education has two goals: the adaptation of specialists to the actual situation in professional activity at a given time; the training of specialists capable of perceiving and developing emerging trends in their professional activity in the future.

Requirements for the system of postgraduate education from the ordering party:

- The credibility of the system of professional development and the guaranteed level of high quality of education;

- The possibility of choosing forms and terms of continuing education; the combination of various forms of education (full-time, short-term seminars and consultations, participation in active forms of obtaining postgraduate education: seminars, conferences, exhibitions and the possibility of publication, etc.);

- Providing opportunities for broad communication with various specialists and creating the creative learning environment;

- The requirement for saturation and information and creative "density" of the process of advanced training [14].

Postgraduate architectural and art education includes the following forms of education: master's, post-graduate, and doctoral; advanced training courses; internship; public forms of advanced training.

Auxiliary and, perhaps, the most basic elements directly influencing the educational system, without which there cannot exist this system, are interweaved with the educational fabric; these elements create prerequisites and order for education itself: the system of cultural and entertainment centers (museums, exhibition halls, galleries, and art - parks); trade unions (the Union of Artists, the Union of Designers, the Union of Architects); the system of consumer services (art salons and art shops); production sphere (design offices, printing, advertising, furniture, 
ceramics, glass products, fabrics, automotive production, and others). All these systems and activities directly affect the quality of education at any level of the educational stage. No matter how we create an ideal model of the system of continuous architectural and art education, it will not work unless there are museums and exhibition halls, there are art shops, there are creative and trade unions, and most importantly there is employment of graduates in design bureaus, factories, and design studios. All this is possible in large cities and large industrial regions, where the conditions for creation and functioning of this model are created.

\section{CONCLUSION}

Many prominent figures of architecture and design and representatives of various art and design schools see in the means of total design ability to influence cultural, social and political life of society, these tools strive to give the person the environment that will make absurd all existing contradictions in the world. As we see, the goals are high, but the reality existing in Russia and abroad is different.

The problem state in Russia, connected with socioeconomic and political changes, the decrease in the birth rate, the transition to the Anglo-American system of education adversely affected the development of continuous architectural and artistic education in the country.

The analysis of SAHO in various regions of Russia revealed tendencies of architectural and town-planning organizing the systems of continuous architectural and art education (Gzhel district, the Ural region) [15].

The main way to solve the problems of Russian education at the current stage of development is the following: this is a change in the social status of architectural and artistic education, that is, in addition to professional education, basic creative education of citizens of the country is needed; the conceptual orientation is focused on "the development of the creative personality"; transformations should be evolutionary and permanent in nature and fulfilled by the subjects of education; the emergence of various unique educational models in architectural schools; the expansion of the existing network of architectural and art universities and faculties in Russia. The author developed the model of the system of continuous architectural and art education, which is able to function in a large region. It is necessary that the solution of these tasks be elevated to the rank of state policy and be solved at the national level.

\section{REFERENCES}

[1] Reader for Design. Tyumen: Institute of Design, 2005, pp.47.

[2] V.I. Stepanov, L.B. Mirchevskaya, Organization of a network of institutions for extracurricular work in cities (Recommendations). Moscow: Stroiizdat, 1975, pp. 48.

[3] L.E. Malakhova, Architectural Education. "A look from the inside". Architecture and construction of Russia, 1999, no.1,pp.23-25.

[4] Order "On the Concept of Modernizing Russian Education for the Period to 2010" Ministry of Education of the Russian Federation of 11.02.2002, Moscow, no. 393. (in Russian).
[5] A.P. Kudryavtsev, A.V. Stepanov, N.F. Metlenkov, Yu.P. Volchok, Architectural Education: Development Problems. Moscow: Editorial URSS, 2002

[6] V.M.Chigarkov, A.L.Dizhur, Project culture and children. Technical Aesthetics. Moscow: 1990, no. 4. pp.2-7., no.5. pp.11-15.

[7] A.G. Ustinov, Design in the Japanese school. Technical Aesthetics, 1988, no.6, pp.11-15.

[8] Reader for Design, pp. 602-613.

[9] A.A. Andreeva, Gzhel: from game to profession. Moscow: Gzhel LLP, Specialist LLP, 1994, p.19-32.

[10] A.T.Gazizova, The system of continuous art education as a factor of influence on the cultural education of the subject (example of Yekaterinburg).In the collection: Modernization of culture: we go and paradigms of cultural changes. Materials of the International Scientific and Practical Conference. Samara State Institute of Culture. Samara, 2014, pp. 304-308.

[11] A.T. Gazizova, Architectural typology of the institutions of the system of continuous architectural and artistic education (on the example of the Samara region).Thesis for the degree of Candidate of Architecture. Samara, 2006

[12] A.P. Kudryavtsev, A.V. Stepanov, N.F. Metlenkov, Yu.P. Volchok, Architectural Education: Development Problems, p. 60.

[13] A.P. Kudryavtsev, A.V. Stepanov, N.F. Metlenkov, Yu.P. Volchok, pp.76-77.

[14] Ibid., p.131.

[15] A.T. Gazizova, Architectural typology of the institutions of the system of continuous architectural and artistic education (on the example of the Samara region).Thesis for the degree of Candidate of Architecture. Samara, 2006. 